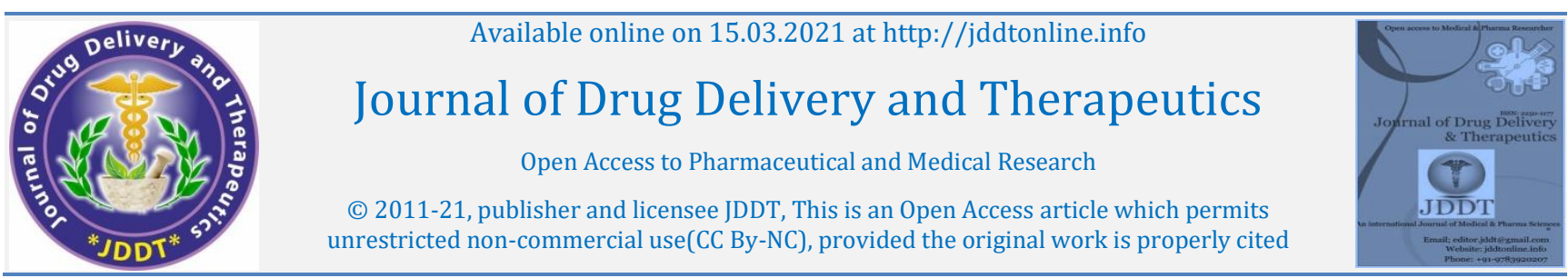

(C) 2011-21, publisher and licensee JDDT, This is an Open Access article which permits
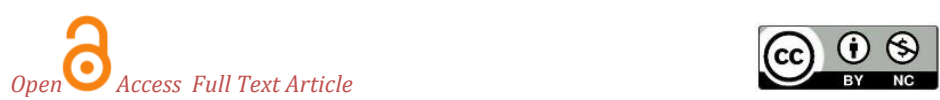

Research Article

\title{
Simultaneous Estimation and Validation of Artemether and Lumefantrine by UV Spectrophotometry in Tablet
}

\author{
Megha Mishra, Anand Mundada \\ Department of Pharmacy, Barkatullah University, Bhopal MP India
}

Article Info:

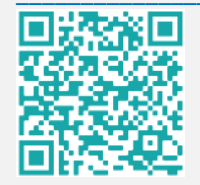

\section{Article History:}

Received 21 Dec 2020;

Review Completed 10 Feb 2021

Accepted 22 Feb 2021;

Available online 15 March 2021

Cite this article as:

Mishra M, Mundada A, Simultaneous Estimation and Validation of Artemether and Lumefantrine by UV

Spectrophotometry in Tablet, Journal of Drug Delivery and Therapeutics. 2021; 11(2):16-22

DOI: http://dx.doi.org/10.22270/jddt.v11i2.4776

\section{Abstract}

A UV spectrophotometric method has been developed for the simultaneous determination of Artemether and Lumefantrine. The spectroscopic method for estimation of Artemether and Lumefantrine employed Area under curve method for analysis using Ethanol as solvent. Artemether has absorbance maxima $253.2 \mathrm{~nm}$ and Lumefantrine has absorbance maxima $235.2 \mathrm{~nm}$ and both these drugs obey Beer's law in concentration range of $4.24-67.84 \mu \mathrm{g} / \mathrm{ml}$ for Artemether and $4.68-28.08 \mu \mathrm{g} / \mathrm{ml}$ for Lumefantrine. The recovery studies ascertained the accuracy of the purposed method and the results were validated as per ICH guidelines. The results were found satisfactory and reproducible. The method was applied successfully for the estimation of Artemether and Lumefantrine in tablet dosage form without the interference of common excipients.

Keywords: Artemether, Lumefantrine; Area under curve; Simultaneous; Estimation

*Address for Correspondence:

Ms. Megha Mishra, Department of Pharmacy, Barkatullah University, Bhopal MP India

\section{INTRODUCTION}

India is amongst top three generic manufacturers of drugs in the world which holds $23 \%$ share of generic market. According to FDA only those drugs, which will be proved to be pharmaceutical and biological equivalent to the branded formulation may be sold into the market ${ }^{1}$.Various methods are available for the analysis of the analysis of the pharmaceuticals, such as titrimetric, gravimetric, polarography, chromatography, spectrophotometry etc. In some case extraction of mixture may be required to estimate them quantitatively ${ }^{1-2}$. In some cases analytical methods for some drug, their combination or their specific dosage form may not be available. The existing analytical procedures may require expensive instruments, reagents and solvents or may be time consuming. It may also involve cumbersome extraction and separation procedures and these may not be reliable 3 . Under these circumstances and effective, rapid, accurate, precise, and cost effective method is required to verify identity, purity and potency of active pharmaceutical ingredient ${ }^{3}$.

UV spectroscopy is a comprehensive and proven option that has been successfully used in the analysis of pharmaceuticals, plant constituents, food products, biomolecules, environmental and metallurgic sciences etc ${ }^{4-8}$. Since past 35 years, it is one of most widely used methods for quick and easy determination of quality, authenticity and purity of the raw materials, crude drugs and market formulations. In many applications other technique could be employed but none rival UV-Visible spectrometry for its simplicity, versatility, speed, accuracy and cost effectiveness. Ultraviolet-visible spectroscopy or ultraviolet-visible spectrophotometry (UV-Vis or UV/Vis) refers to absorption spectroscopy or reflectance spectroscopy in the ultravioletvisible spectral region 9-12. This means it uses light in the visible and adjacent (near-UV and near-infrared (NIR)) ranges. The absorption or reflectance in the visible range directly affects the perceived color of the chemicals involved. In this region of the electromagnetic spectrum, molecules undergo electronic transitions. This technique is complementary to fluorescence spectroscopy, in that fluorescence deals with transitions from the excited state to the ground state, while absorption measures transitions from the ground state to the excited state ${ }^{12-17}$.

The basis of all the spectrophotometric techniques for multi component samples is the property that at all wavelengths-

$\checkmark$ The absorbance of a solution is the sum of absorbance of a solution is the sum of absorbance of the individual component.

$\checkmark$ The measured absorbance is a difference between the total absorbance of the solution in the sample cell and that of the solution in the reference cell ${ }^{6}$.

\section{MATERIALS AND METHODS}

\section{Procurement of drug and chemical}

Working Standard of artemether and lumefantrine were obtained as a gift sample from MMC HEALTHCARE 34 B Sidco Industrial Estate, Thirumazhisai Chennai 602107. 


\section{Selection of solvent system}

An ideal solvent should not absorb in the region where analyte gives absorption also it should be cheap, stable and should not interfere with the analyte the solubility of the artemether and lumefantrine was tested on methanol, ACN and the different combination of ACN: methanol, methanol and HCL. Out of all combination tested was found to be both the drug easily soluble in prepared $1 \mathrm{~N}$ Methanolic HCL, which is cheap. Since UV cutoff of methanol and HCL are 205 $\mathrm{nm}$ and $190 \mathrm{~nm}$ respectively, this solvent will not interfere with the analyte in UV region, thus 1N Methanolic HCL was selected as a solvent of the proposed method ${ }^{1-3}$.

\section{Preparation of solvent system}

Taken $42.5 \mathrm{ml}$ HCL in a $100 \mathrm{ml}$ calibrated volumetric flask and added $400 \mathrm{ml}$ of methanol.

\section{Standardization of solvent system}

Firstly anhydrous Sodium carbonate dried at $270{ }^{\circ} \mathrm{C}$ for 1 hour 5 and during this period prepared $500 \mathrm{ml}$ of methanolic HCL after that taken methanolic HCL in a burette and taken $10 \mathrm{ml}$ solution of anhydrous sodium carbonate in a calibrated iodimetric flask. Methylene red reagent used as indicator 6 .

Added 3 drops methylene red indicator in iodimetric flask, titration was started, pink colour was produced but titration was continuing tilled pink colour was not be disappear. When pink colour was disappeared then note down the readings. This procedure repeated for 3 times and average readings was note down.

\section{Preparation of calibration curve}

\section{Material}

Working standard of Artemether and lumefantrine, measuring cylinder, volumetric flask, conical flask, pipette, burette, magnetic stirrer, magnetic bead, the rmometer. Weighing bottle, weighing balance (CY-204, Citizen), ultrasonicator (Jyoti), UV spectrophotometer (V 530 Jasco), cuvette (optiglass).

\section{Preparation of stock solution}

Standard stock solution $(105 \mu \mathrm{g} / \mathrm{ml})$ of artemether was prepared by transferring approximately but accurately weighed $2.1 \mathrm{mg}$ of artemether in $10 \mathrm{ml}$ calibrated volumetric flask and added $10 \mathrm{ml}$ prepared methanolic HCL. Flask were shaken for few seconds and heated on the water bath for 3 hours at temperature $60 \pm 5 \stackrel{\circ}{\circ}$. The solutions were allowed to cool at room temperature and volume was made up to mark with $20 \mathrm{ml}$ methanol .from this stock solution different dilutions were prepared ranging from $4.2 \mu \mathrm{g} / \mathrm{ml}$ to 67.20 $\mu \mathrm{g} / \mathrm{ml}$.

Standard stock solution $(115 \mu \mathrm{g} / \mathrm{ml})$ of artemether was prepared by transferring approximately but accurately weighed $2.3 \mathrm{mg}$ of artemether in $10 \mathrm{ml}$ calibrated volumetric flask and added $10 \mathrm{ml}$ prepared methanolic HCL. Flask were shaken for few seconds and heated on the water bath for 3 hours at temperature $60 \pm 5 \stackrel{\circ}{\circ}$. The solutions were allowed to cool at room temperature and volume was made up to mark with $20 \mathrm{ml}$ methanol from this stock solution different dilutions were prepared ranging from $4.6 \mu \mathrm{g} / \mathrm{ml}$ to 32.2 $\mu \mathrm{g} / \mathrm{ml}$.

Blank was prepared by heating $5 \mathrm{ml}$ of methanolic HCL in the same condition and diluting up to the $10 \mathrm{ml}$ with methanol.

\section{Determination of absorption maxima of artemether}

$1 \mathrm{ml}$ of Stock solution of artemether was pipette out in to 10 $\mathrm{ml}$ calibrated volumetric flask and volume was made up to mark with methanol. The final concentration of drugs was $67.20 \mu \mathrm{g} / \mathrm{ml}$. The solution was than scanned in the UV region 200-400 $\mathrm{nm}$ to get absorbance maxima using blank. The absorbance maximum was found to be $253.2 \mathrm{~nm}$.

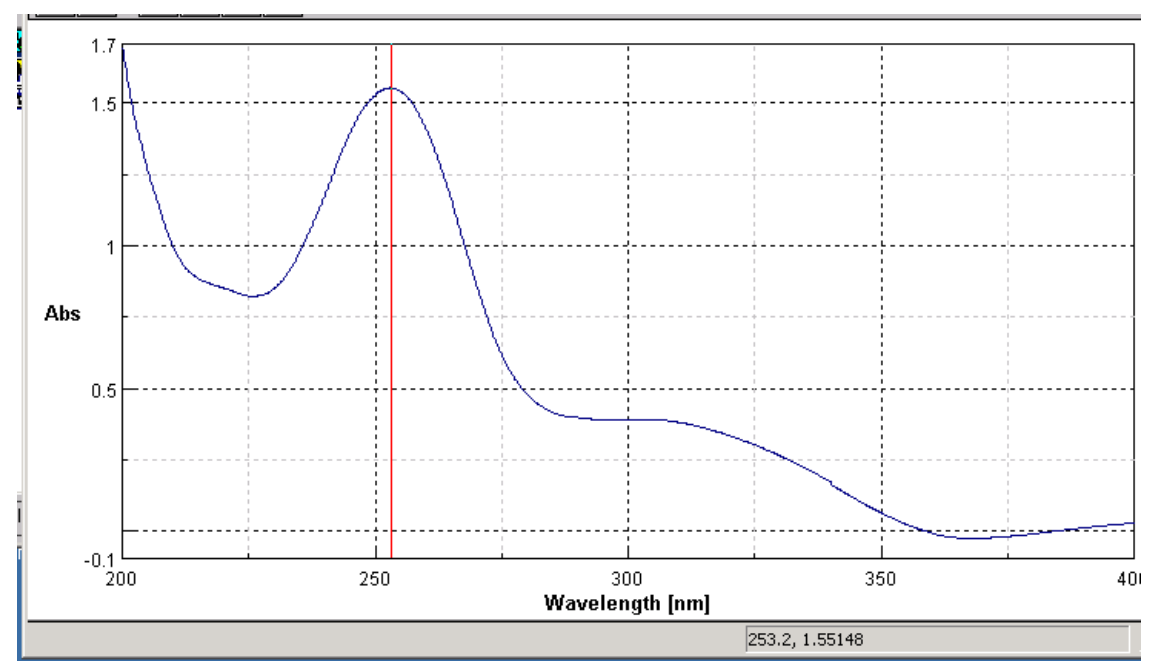

Figure 1: Artemether shows the $\lambda \max$ at $253.2 \mathrm{~nm}$ in prepared $1 \mathrm{~N}$ methanolic HCL (methanol).

\section{Determination of absorption maxima of Lumefantrine}

$1 \mathrm{ml}$ of stock solution $(115 \mu \mathrm{g} / \mathrm{ml})$ of lumefantrine was pipette out in to $10 \mathrm{ml}$ volumetric flask and volume was made up to mark with methanol. The final concentration of drugs was $32.20 \mu \mathrm{g} / \mathrm{ml}$. The solution was scanned in UV region 200-400 $\mathrm{nm}$ to get absorption maxima using methanolic HCL (methanol) as Blank. The absorbance was found to be $235.2 \mathrm{~nm}$. 


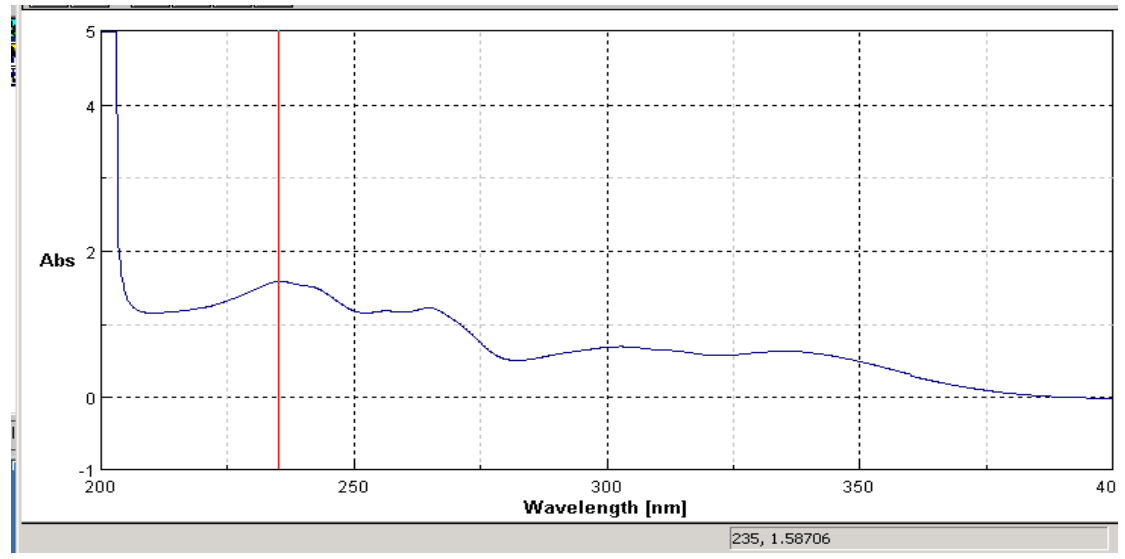

Figure 2: Lumefantrine shows the $\lambda$ max at $235.2 \mathrm{~nm}$ in prepared $1 \mathrm{~N}$ methanolic HCL (methanol).

\section{Preparation of calibration curve of artemether}

The calibration curve was prepared by measuring absorbance of various concentration of artemether against 1Nmethanolic HCL (methanol) as blank. The graph was plotted for studying the linear relationship between absorbance and concentration.

\section{Procedure}

Standard stock solution was prepared by transferring approximately but accurately weighed $2.12 \mathrm{mg}$ of artemether in $10 \mathrm{ml}$ calibrated volumetric flask added $10 \mathrm{ml}$ prepared $1 \mathrm{~N}$ methanolic HCL flask were shaken for few seconds and heated on the water bath for 3 hours at temperature $60 \pm 5^{\circ} \mathrm{C}$.the solutions were allowed to cool at room temperature and volume was made up to mark with $20 \mathrm{ml}$ methanol from this stock solution different dilutions were prepared ranging from $4.24 \mu \mathrm{g} / \mathrm{ml}$ to $67.84 \mu \mathrm{g} / \mathrm{ml}$.

Blank was prepared by heating $5 \mathrm{ml}$ of methanolic HCL in the same condition and diluting up to the $10 \mathrm{ml}$ with methanol.

The absorbances of dilutions were scanned at both the wavelength (253.2 and 235.2) against blank. These dilutions were also scanned in UV region 200-400nm to get absorbance at both wavelength.

Table 1: Dilutions for calibration curve of artemether at $253.2 \mathrm{~nm}$

\begin{tabular}{|c|c|c|}
\hline S. No. & Concentration $(\boldsymbol{\mu g} / \mathbf{m l})$ & Absorbance \\
\hline 1. & 0 & 0 \\
\hline 2. & 4.24 & 0.1241 \\
\hline 3. & 8.48 & 0.2595 \\
\hline 4. & 16.96 & 0.5488 \\
\hline 5. & 33.92 & 1.1794 \\
\hline 6. & 67.84 & 2.3831 \\
\hline
\end{tabular}

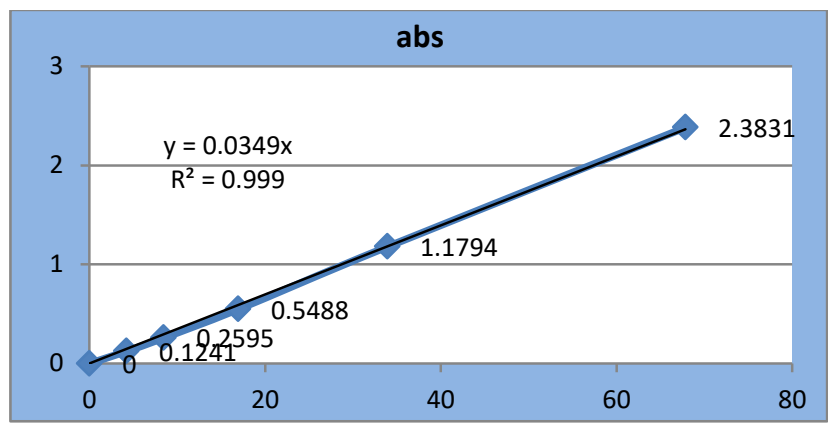

Figure 3: Artemether shows the linearity range of 4.24 to $67.84 \mu \mathrm{g} / \mathrm{ml}$ having the line equation of $\mathrm{y}=0.034 \mathrm{x}$ and regression value of 0.999 .The regression value indicates that the point lies near the line approaches 1 .
Table 2: Dilutions for calibration curve of artemether at $235.2 \mathrm{~nm}$

\begin{tabular}{|c|c|c|}
\hline S. No & Concentration $(\boldsymbol{\mu g} / \mathbf{m l})$ & Absorbance \\
\hline 1 & 0 & 0 \\
\hline 2 & 4.24 & 0.06257 \\
\hline 3 & 8.48 & 0.12571 \\
\hline 4 & 16.96 & 0.26292 \\
\hline 5 & 33.92 & 0.59403 \\
\hline 6 & 67.84 & 1.20042 \\
\hline
\end{tabular}

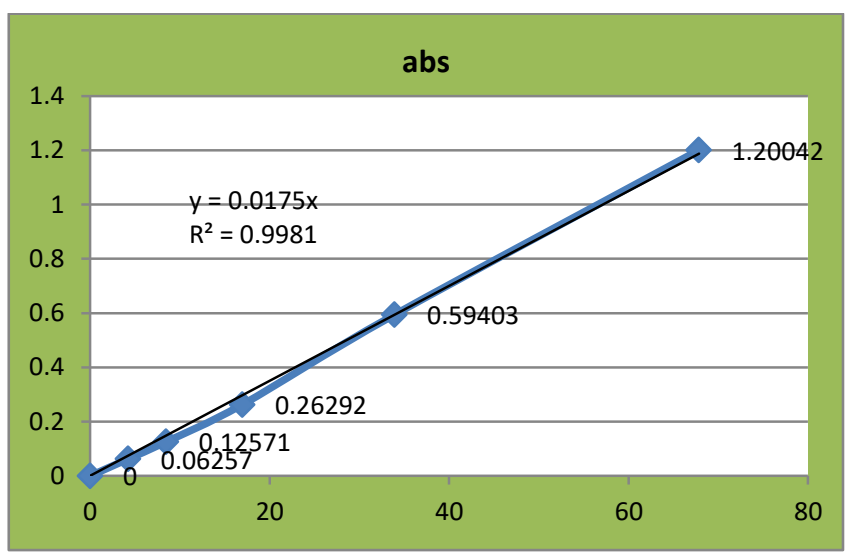

Figure 4: Artemether shows the linearity range of 4.24 to $67.84 \mu \mathrm{g} / \mathrm{ml}$ having the line equation of $\mathrm{y}=0.017$ and regression value of 0.998 .The regression value indicates that the point lies near the line approaches 1 .

\section{Preparation of calibration curve of lumefantrine}

The calibration curve was prepared by measuring absorbance of various concentration of lumefantrine against $1 \mathrm{~N}$ methanolic HCL (methanol) as blank. The graph was plotted for studying the linear relationship between absorbance and concentration.

\section{Procedure}

Standard stock solution was prepared by transferring approximately but accurately weighed $2.34 \mathrm{mg}$ of lumefantrine in $10 \mathrm{ml}$ calibrated volumetric flask added 10 ml prepared $1 \mathrm{~N}$ methanolic HCL flask were shaken for few seconds and heated on the water bath for 3 hours at temperature $60 \pm 5^{\circ} \mathrm{C}$.the solutions were allowed to cool at room temperature and volume was made up to mark with $20 \mathrm{ml}$ methanol .from this stock solution different dilutions were prepared ranging from $4.68 \mu \mathrm{g} / \mathrm{ml}$ to $28.08 \mu \mathrm{g} / \mathrm{ml}$. Blank was prepared by heating $5 \mathrm{ml}$ of methanolic HCL in the same condition and diluting up to the $10 \mathrm{ml}$ with methanol. The absorbances of dilutions were scanned at both the 
wavelength (235.2 and 253.2) against blank. These dilutions were also scanned in UV region 200-400 $\mathrm{nm}$ to get absorbance at both wavelengths.

Table 3: Dilutions for calibration curve of lumefantrine at $235.2 \mathrm{~nm}$

\begin{tabular}{|c|c|c|}
\hline S. No. & Concentration $(\boldsymbol{\mu g} / \mathbf{m l})$ & Absorbance \\
\hline 1. & 0 & 0 \\
\hline 2. & 4.68 & 0.2959 \\
\hline 3. & 9.36 & 0.6805 \\
\hline 4. & 14.04 & 0.9985 \\
\hline 5. & 18.72 & 1.3320 \\
\hline 6. & 23.40 & 1.6885 \\
\hline 7. & 28.08 & 2.0404 \\
\hline
\end{tabular}

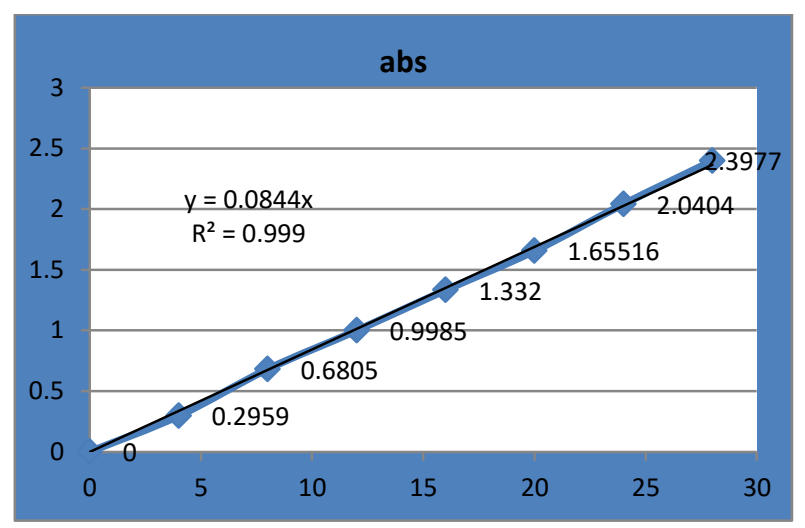

Figure 5: Lumefantrine shows the linearity range of 4.68 to $28.08 \mu \mathrm{g} / \mathrm{ml}$ having the line equation of $\mathrm{y}=0.084 \mathrm{x}$ and regression value of 0.999 .The regression value indicates that the point lies near the line approaches 1 .
Table 4: Dilutions for calibration curve of lumefantrine at $253.2 \mathrm{~nm}$

\begin{tabular}{|c|c|c|}
\hline S. No. & $\begin{array}{c}\text { Concentration } \\
(\boldsymbol{\mu g} / \mathbf{m l})\end{array}$ & Absorbance \\
\hline 1. & 4.68 & 0.28382 \\
\hline 2. & 9.36 & 0.58384 \\
\hline 3. & 14.04 & 0.95866 \\
\hline 4. & 18.72 & 0.16736 \\
\hline 5. & 23.40 & 1.58322 \\
\hline 6. & 28.08 & 1.98597 \\
\hline
\end{tabular}

Graph 4: From the graph 4 it was cleared that the lumefantrine shows the linearity range of 4.68 to $28.08 \mu \mathrm{g} / \mathrm{ml}$ having the line equation of $y=0.068 \mathrm{x}$ and regression value of 0.997.The regression value indicates that the point lies near the line approaches 1

\section{Molar absorptivity and percent absorptivity}

Molar absorptivity $(\Sigma)$ it is a measurement of how strongly a chemical species absorb light at a given wavelength. It is an intrinsic property of the species ${ }^{7}$.The actual absorbance (A) of a sample is dependent on the path length (I) and the concentration (c) and is given as-

$$
\text { [ } \mathbf{A}=\Sigma \mathbf{c l}]
$$

The unit used to describe the molar absorptivity is $\mathrm{L} / \mathrm{mol} / \mathrm{cm}^{8}$.

\section{Calculation of molar absorptivity:}

Molar absorptivity $(\Sigma)=$ Absorbance $/$ molar concentration

Calculation of percent absorptivity: $\mathrm{c} /$ Absorptivity = Absorbance/concentration in g/liter.

Table 5: Molar absorptivity and percent absorptivity of artemether and lumefantrine

\begin{tabular}{|c|c|c|c|c|}
\hline Wavelength(nm) & $\begin{array}{c}\text { Molar absorptivity } \\
(\Sigma) \text { of artemether }\end{array}$ & $\begin{array}{c}\text { Molar absorptivity } \\
(\Sigma) \text { of lumefantrine }\end{array}$ & $\begin{array}{c}\text { \% absorptivity of } \\
\text { artemether }\end{array}$ & $\begin{array}{c}\text { \%o absorptivity of } \\
\text { lumefantrine }\end{array}$ \\
\hline 253.2 & 114602.38 & 170.8498174 & 341.973524 & 5725.53 \\
\hline 235.2 & 570.0946934 & 136510.75 & 107932.82 & 721.0416282 \\
\hline
\end{tabular}

Table 5 shows molar absorptivity and \% absorpivity of both the drugs. To check the working range for the proposed method the working standards of the both drugs were mixed in 1:6, 6:1 and 3.5:3.5 and scanned at analytical wavelength 253.2 and $235.2 \mathrm{~nm}$ and concentration of both the drug was analyzed.

\section{Determination of artemether and lumefantrine in tablets}

Twenty tablets were powdered and weight equivalent to approx.10 mg of artemether was weighed accurately and dissolved in $10 \mathrm{ml}$ prepared $1 \mathrm{~N}$ methanolic HCL. Flask were shaken for few seconds and heated on the water bath for 3 hours at temperature $60 \pm 5 \stackrel{\circ}{\circ}$. The solutions were allowed to cool at room temperature. The solution after filtration through whattman filter paper no. 41 was quantitatively transferred to $10 \mathrm{ml}$ calibrated volumetric flask and the volume was made up to $20 \mathrm{ml}$ prepared $1 \mathrm{~N}$ methanolic HCL by continuously washing filter paper to quantitatively transfer the total amount of drug. In a $10 \mathrm{ml}$ calibrated volumetric flask $1 \mathrm{ml}$ of the sample solution was placed and volume was made up to $10 \mathrm{ml}$ with methanol and absorbance was measured at 253.2 and $235.2 \mathrm{~nm}$ against blank (Blank was prepared by heating $5 \mathrm{ml}$ of methanolic HCL in the same condition and diluting up to the $10 \mathrm{ml}$ with methanol)

\section{RESULTS AND DISCUSSION}

\section{Validation of developed method}

The developed methods for simultaneous estimation of artemether and lumefantrine were validated as per ICH guidelines (ICH 1996). 
Table 6: Parameters for method validation with references to ICH, USP and ISO guidelines.

\begin{tabular}{|c|c|c|}
\hline S. No. & Parameters & Official in \\
\hline 1 & Specificity & USP,ICH \\
\hline 2 & Selectivity & ISO 17025 \\
\hline 3 & Precision & USP,ICH \\
\hline 4 & Repeatability & ICH ISO 17025, \\
\hline 5 & Intermediate precision & ICH \\
\hline 6 & Reproducibility & ICH \\
\hline 7 & Accuracy & USP,ICH, ISO 17025 \\
\hline 8 & Linearity & USP,ICH,ISO 17025 \\
\hline 9 & Limit of detection & USP,ICH,ISO 17025 \\
\hline 10 & Limit of quantitation & USP,ICH,ISO 17025 \\
\hline 11 & Robustness & USP Included in \\
& & ICH,ISO \\
\hline 12 & Range & USP,ICH \\
\hline
\end{tabular}

\section{Linearity}

The linearity of proposed method was determined from the calibration curve data of both the drugs that is artemether and lumefantrine. Artemether shows linear response between 4.24-67.84 $\mu \mathrm{g} / \mathrm{ml}$ and lumefantrine shows linear response between 4.68-28.08 $\mu \mathrm{g} / \mathrm{ml}$. Acceptance criteria usually involve a Goodness of Fit test. A high correlation coefficient $\left(\mathrm{r}^{2}\right)$ of 0.97 is often used as criterion of linearity. However this is not sufficient to prove that a linear relationship exists, and a method with a coefficient of determination of less than 0.99 may still fit for process.

Slope $=0.037 \mathrm{x}$ for artemether

Slope $=0.084 \mathrm{x}$ for lumefantrine

$\left(\mathrm{r}^{2}\right)$ for artemether $=0.999$

$\left(\mathrm{r}^{2}\right)$ for lumefantrine $=0.999$

\section{Range}

ICH defines the range of an analytical procedure as the interval from the upper to the lower concentration of analyte in the sample for which it has been demonstrated that the analytical procedure has a suitable level of precision, accuracy and linearity. Range was determined from the data obtained from the study of mixed standard of drugs in different ratios.The range of the method is between $1-6 \mu \mathrm{g} / \mathrm{ml}$.

\section{Limit of detection}

The limit of detection is the lowest concentration of analyte in a sample that can be detected but not necessarily determined in quantitatively using a specific method under the required experimental condition. Such a limit is expressed in term of a concentration of analyte in the sample.

Table 7: Data of both standards for LOD and LOQ:

\begin{tabular}{|c|c|c|}
\hline S. No. & Parameters for artemether & Parameters for lumefantrine \\
\hline Mean & 0.89898 & 1.1726333 \\
\hline Standaed deviation $(\sigma)$ & 0.923748784 & 0.645864312 \\
\hline Relative standard deviation (RSD) & 1.027552097 & 0.550781145 \\
\hline Cofficient of varience $\left(\sigma^{2}\right)$ & 0.853311815 & 0.417140709 \\
\hline
\end{tabular}

\section{Limit of detection of artemether}

[LOD $=3.3 \times \sigma / s]$

Where, Standard deviation $(\sigma)=0.923748784$, Slope of calibration curve (s) $=0.037$, LOD = $3.3 \times 0.923748784 / 0.037=82.38884051 \mu \mathrm{g} / \mathrm{ml}$

\section{LOD of lumefantrine}

Where, Standard deviation $(\sigma)=0.645864312$, Slope of calibration curve $(\mathrm{s})=0.084$, LOD $=3.3 \times$ $0.645864312 / 0.084=25.37324084$

\section{Limit of quantitation}

The Limit of quantitation is the lowest concentration of analyte in a sample which can quantitatively determine with suitable accuracy and precision under the stated operational condition of the method. Limit of quantitation can vary with the type of method employed and the nature of the sample. It is based on the standard deviation of the response and the slope.

\section{Limit of quantitation of artemether \\ $[\mathrm{LOQ}=10 \times \sigma / s]$}

Where, Standard deviation $(\sigma)=0.923748784$, Slope of calibration curve $(\mathrm{s})=0.037, \mathrm{LOQ}=10 \times 0.923748784 / 0.037$ $=230.6248154$

\section{Limit of quantitation of lumefantrine}

Where, Standard deviation $(\sigma)=0.645864312$, Slope of calibration curve $(\mathrm{s})=0.084$, LOQ $=10 \times$ $0.645864312 / 0.084=76.8886085$ 
Table 8: Optical characteristics of the developed method:

\begin{tabular}{|c|c|c|c|}
\hline S. No. & Parameter & For artemether & For lumefantrine \\
\hline 1 & Beers law & $4.24-67.84 \mu \mathrm{g} / \mathrm{ml}$ & $4.68-28.08 \mu \mathrm{g} / \mathrm{ml}$ \\
\hline 2 & $\Lambda \max$ & $253.2 \mathrm{~nm}$ & $235.2 \mathrm{~nm}$ \\
\hline 3 & Molar absorptivity & At $253.2 \mathrm{~nm}$ & At $235.2 \mathrm{~nm}$ \\
& & At $235.2 \mathrm{~nm}$ & At $253.2 \mathrm{~nm}$ \\
\hline 4 & $\%$ absorptivity & At $253.2 \mathrm{~nm}$ & At $235.2 \mathrm{~nm}$ \\
& & At $235.2 \mathrm{~nm}$ & At $253.2 \mathrm{~nm}$ \\
\hline
\end{tabular}

Table 9: Summary of validated method

\begin{tabular}{|c|c|c|c|}
\hline S. No. & Parameters & For artemether & For lumefantrine \\
\hline 1 & Linearity & $4.24-67.84 \mu \mathrm{g} / \mathrm{ml}$ & $4.68-28.08 \mu \mathrm{g} / \mathrm{ml}$ \\
\hline 2 & Range & $1-6 \mu \mathrm{g} / \mathrm{ml}$ & $1-6 \mu \mathrm{g} / \mathrm{ml}$ \\
\hline 3 & Correlation coefficient & 0.999 & 0.999 \\
\hline 4 & LOD & 82.38884051 & 76.88860857 \\
\hline 5 & LOQ & 230.6248154 & 0.645864312 \\
\hline 6 & Standard deviation & 0.923748784 & 0.550781145 \\
\hline 7 & RSD & 1.027552097 & 0.417140709 \\
\hline 8 & Cofficient of varience & 0.853311815 & 1.172633 \\
\hline 9 & Mean & 0.89898 & 0.084 \\
\hline 10 & Slope & 0.037 & \\
\hline
\end{tabular}

The present work is a discussion on simultaneous estimation and validation of artemether and lumefantrine in tablet dosage form by UV spectrophotometry.

On the literature survey, it was found that artemether and lumefantrine can be estimated independently by several HPLC, other analytical methods and few individual methods are available for estimation of artemether and lumefantrine by UV spectrophotometry, since relatively no methods are available for estimation of artemether and lumefantrine in combined dosage form, it was felt that necessary to develop a specific method for their combination.

Simultaneous spectroscopic estimation of artemether and lumefantrine was done by simultaneous equation method, where as individual form artemether and lumefantrine were estimated by using prepared $1 \mathrm{~N}$ methanolic HCL as solvent and from calibration curve. The artemether shows absorption maxima at 253.2 and lumefantrine shows absorption maxima at 235.2 Beer's law is obeyed over a concentration range of $4.24-67.84 \mu \mathrm{g} / \mathrm{ml}$ and for lumefantrine $4.68-28.08 \mu \mathrm{g} / \mathrm{ml}$. The developed method per validated as per ICH guidelines 1996.

\section{CONCLUSION}

The UV spectroscopic method developed for quantitative determination of artemether and lumefantrine is rapid, economic, linear, reproducible, specific and cost effective. The method was validated showing satisfactory data for all the method validation parameters tested. The developed method can be used for routine analysis of in process quality control and marketed samples of artemether and lumefantrine.

\section{REFERENCES}

1. Annerberg A, Blessborn D, Bergqvist Y, Day N, White NJ, Development and validation of a bioanalytical method using automated solid-phase extraction and LC-UV for the simultaneous determination of lumefantrine and its desbutyl metabolite in plasma, In J Pharm Biomed Anal, 2005; 37 (5):1081-8.

2. Blessborn D, Römsing S, Annerberg A, Sundquist D, Björkman A, Lindegardh N, Bergqvist $Y$, Development and validation of an automated solid-phase extraction and liquid chromatographic method for determination of lumefantrine in capillary blood on sampling paper, J Pharm Biomed Analys.2007; 45(2):282-7.

3. César Ida C, Andrade Nogueira FH, Antônio Pianetti G, Simultaneous determination of artemether and lumefantrine in fixed dose combination tablets by HPLC with UV detection, J Pharm Biomed Anal, 2008; 4; 48(3):951-4.

4. Colussi D, Parisot C, Legay F, Lefevre G, Binding of artemether and lumefantrine to plasma proteins and erythrocytes Eur J Pharm Sci. 1999;9:9-16.

5. da Costa César I, Nogueira FH, Pianetti GA, Comparison of HPLC, UV spectrophotometry and potentiometric titration methods for the determination of lumefantrine in pharmaceutical products, Pharm Biomed Anal, 2008; 48 (1):223-6.

6. Fifield F.W. , Kealey D, 5th Edition, Black Well Science Ltd. Principles and Practice of Analytical Chemistry, (2000) pp. 270 $-276$.

7. Hokanson G.C., A Life Cycle Approach to the Validation of Analytical Methods During Pharmaceutical Product Development, Part - II: Changes and the Need for Additional Validation, Pharm. Tech., 92 -100 (1994).

8. Hodel EM, Zanolari B, Mercier T, Biollaz J, Keiser J, Olliaro P, Genton B, Decosterd LA, A single LC-tandem mass spectrometry method for the simultaneous determination of 14 antimalarial drugs and their meta- bolites in human plasma, J Chromatogr B, 2009; 877(10):867-86. 
9. International Conference of Harmonization (ICH) of Technical Requirements for the Registration of Pharmaceuticals for Human Use, Validation of Analytical Procedures: Methodology, Adopted in Geneva (1996).

10. Isabela da Costa César, , Fernando Henrique Andrade Nogueira and Gérson Antônio Pianetti, Simultaneous determination of artemether and lumefantrine in fixed dose combination tablets by HPLC with UV detection, Journal of Pharmaceutical and Biomedical Analysis, 2008; 48(3):951-954

11. Vessman J, Selectivity or Specificity? Validation of Analytical Methods from the Perspective of an Analytical Chemist in the Pharmaceutical Industry, J. Pharm and Biomed. Anal., 1996; $14: 867-869$.

12. Green J.M.. A Practical Guide to Analytical Method Validation, Anal. Chem. News and Features, 305A - 309A (1996)

13. Lindegårdh N Wahajuddin, Singh SP, Jain GK, Determination of lumefantrine in rat plasma by liquid-liquid extraction using LC-
MS/MS with electrospray ionization: assay development, validation and application to a pharmacokinetic study, J Chromatogr B, 2009; 877 (11-12):1133-9.

14. Sisowath C, Stromberg J, Martensson A, Msellem M, Obondo C, Bjorkman A, Gil JP, In vivo selection of Plasmodium falciparum pfmdr1 $86 \mathrm{~N}$ coding alleles by artemether-lumefantrine (Coartem). J Infect Dis. 2005; 191(6):1014-7.

15. Technical Report Series No. 805. Geneva. 1990.

16. Wahajuddin, Singh SP, Jain GK, Determination of lumefantrine in rat plasma by liquid-liquid extraction using LC-MS/MS with electrospray ionization: assay development, validation and application to a pharmacokinetic study, J Chromatogr B, 2009; 877(11- 12):1133-9.

17. Wegscheider, Validation of Analytical Methods, in: Accreditation and Quality Assurance in Analytical Chemistry, H. Guenzler, Springer (Ed.) Verlag, Berlin (1996). World Health Organization, Practical Chemotherapy of Malaria, W.H.O. 